\title{
Aortic arch stiffness in Fabry disease
}

\author{
Zoubir M Bensalah ${ }^{1 *}$, Cédric Collin ${ }^{3}$, Alban Redheuil ${ }^{2}$, Pierre Boutouyrie ${ }^{3}$, Dominique Germain ${ }^{4}$, Elie Mousseaux ${ }^{2}$ \\ From 16th Annual SCMR Scientific Sessions \\ San Francisco, CA, USA. 31 January - 3 February 2013
}

\section{Background}

Background: Aortic thoracic remodelling has been recently described in FD, however no data was available concerning AAS in this rare genetic disease.

Aim of this study was to assess aortic arch stiffness (AAS) parameters in male patients with Fabry disease (FD) using cardiovascular magnetic resonance imaging (CMR).

\section{Methods}

Twenty nine males with FD matched with 58 controls for age underwent CMR using cine and phase contrast velocity sequences.

Thoracic aortic diameter; local (distensibility, $\beta$-index stiffness), global (pulse wave velocity) stiffness parameters of the aortic arch and cardiac proprieties were assessed by CMR.

\section{Results}

Aortic arch PWV was significantly increased in FD patients $(6.5 \pm 3.1$ vs $5.0 \pm 1.5 \mathrm{~m} / \mathrm{s}, \mathrm{p}<0.01)$

Compared to control subjects, patients with FD had also markedly decreased distensibility $(2.73 \pm 1.14$ vs $3.45 \pm 1.13$ $10-2 \mathrm{kPa}-1, \mathrm{p}<0.01)$ and increased stiffness index beta (9.4 $\pm 6.7 .10-2$ vs $5.9 \pm 2.7 .10-2, \mathrm{p}<0.001)$ in the ascending aorta.

Descending aortic stiffness parameters were also impaired with a trend for decreased distensibility $(2.26 \pm 1.15$ vs 3.15 $\pm 1.010-2 \mathrm{kPa}-1, \mathrm{P}=0.06)$ and significant increased for $\beta$-index stiffness (8.5 \pm 3.9 .10 - 2 vs $2.9 \pm 0.9 .10$ - 2 , $\mathrm{p}<0.0001)$.

\section{Conclusions}

FD patients exhibited impairment of both local and global aortic arch stiffness parameters.

\section{Funding}

Nothing.

${ }^{1}$ Radiology, HOSPITAL AMBROISE PARE, Boulogne-Billancourt, France Full list of author information is available at the end of the article
Author details

'Radiology, HOSPITAL AMBROISE PARE, Boulogne-Billancourt, France.

${ }^{2}$ Cardiovascular Radiology, Hospital George Pompidou, Paris, France.

${ }^{3}$ Departement of Pharmacology, Hospital George Pompidou, Paris, France.

${ }^{4}$ Genetic, Hospital Raymond Poincaré, Garches, France.

Published: 30 January 2013

doi:10.1186/1532-429X-15-S1-E124

Cite this article as: Bensalah et al:: Aortic arch stiffness in Fabry disease. Journal of Cardiovascular Magnetic Resonance 2013 15(Suppl 1):E124.

Submit your next manuscript to BioMed Central and take full advantage of:

- Convenient online submission

- Thorough peer review

- No space constraints or color figure charges

- Immediate publication on acceptance

- Inclusion in PubMed, CAS, Scopus and Google Scholar

- Research which is freely available for redistribution 